\title{
CORPORATE CRIMINAL LIABILITY IN TERMS OF ATTRIBUTABILITY CONCEPT ${ }^{1}$
}

\author{
Jakub Lorko, Matej Smalik \\ Comenius University in Bratislava, Faculty of Law
}

LORKO, J., SMALÍK, M. Corporate Criminal Liability in Terms of Attributability Concept. Bratislava Law Review, Vol. 3, No. 2 (2019), pp. 34 - 46. ISSN 2585-7088, eISSN: 2644-6359

\begin{abstract}
In this paper the authors analyse the introduced model of genuine corporate criminal liability in the Slovak Republic. Genuine corporate criminal liability is described in a more simplified way through the obligatory elements of corporate criminal liability. The authors also focus and conclude on practical reflections about potential excesses in the enforcement of the corporate criminal liability.
\end{abstract}

Key words: crime, corporate criminal liability, substantial aspects, attributability concept, criminal law, Slovak jurisdiction

\section{$1 \quad$ INTRODUCTION}

Corporate criminal liability represents a specific issue in the area of criminal law within the Slovak legal system. Previously, this issue was especially subject to differences in opinions presented in this respect by professional public and these were also reflected in the initial and unsuccessful attempts to introduce the so-called genuine corporate criminal liability during the criminal code's recodification period from 2004 to 2007 . Failure to introduce genuine corporate criminal liability resulted in an "experiment" resulting in the introduction of the so-called non-genuine or pseudo-corporate criminal liability. The given legal regulation was refused by the application practice and this has most accurately been evidenced by "zero application" of related legal institutes of non-genuine corporate criminal liability in practice.

As of 1 July 2016, special Act No. 91/2016 Coll. on Corporate Criminal Liability and on Amendments and Supplements to Certain Acts (hereinafter only referred to as "ACCL") came into effect. The given legal regulation derogated the legal institutes of the non-genuine corporate criminal liability stipulated in the Criminal Code and at the same time introduced the model of genuine corporate criminal liability which is based mainly on the basis of "attributability concept".

Dissatisfaction resulting from the disputable and obsolete legal regulation of non-genuine corporate criminal liability was also noticed at a supranational level. The Slovak Republic is a party to OECD's Convention on Combating Bribery of Foreign Public Officials in International Business Transactions and being regularly evaluated. In the report prepared in the third phase of Slovak Republic evaluation, it was stated that there is an absence of an effective regulation of corporate

1 Publication is supported by Slovak research and development agency on the basis of the contract no. APVV-15-0740 Guidelines and tools for effective elimination of unlawful acts in relation with potential insolvency. 
responsibility vis-à-vis the sanctioning of bribing foreign public officials in international business transactions. According to the evaluation report, the legal regulation of corporate criminal liability contained in the Criminal Code may not be considered as effective and one satisfying the conditions arising out of this Convention of OECD. In fact, the evaluation report referred to the former Slovak legal regulation as the regulation of confiscations in respect of legal entities which is a sanction liability rather than a corporate criminal liability.

With the aim of fulfilling the recommendations pronounced in the evaluation report, it is inevitable to take into account the criteria contained in the evaluation report in the process of drafting new legal regulation thereof. These criteria are described in detail in a material entitled "Measures Proposed to Ensure the Satisfaction of Recommendations Adopted by OECD Working Group on Bribery in International Business Transactions for the Slovak Republic in Phase 3 of Its Assessment". The government of the Slovak Republic debated this material and approved it through its resolution No. 137 on 20 March 2013. One of the obligations arising out of the above-mentioned resolution issued by the government was an obligation to submit a Corporate Criminal Liability Bill for a government debate. On 28 August 2015, the Ministry of Justice of the Slovak Republic really submitted Government Bill No. 1751 on Corporate Criminal Liability and on Amendments and Supplements to Certain Acts (hereinafter only referred to the "CCL Bill") for a debate held in the National Council of the Slovak Republic.

The process of drafting the wording of this CCL Bill was not easy and the wording changed several times (e.g. change of corporate criminal liability for all criminal offences set out in the Criminal Code to an exhaustive list of criminal offences). There were divided opinions presented by the professional public during the commenting procedure. Nowadays, we can state that the legislative process was completed on 13 November 2015 and ACCL was published in the Collection of Laws of the Slovak Republic on 25 February and it came into effect on 1 July 2016. After more than a decade, a special Act introducing the so-called genuine corporate criminal liability was adopted and incorporated in the Slovak law. While drafting this Act, the lawmaker was primarily inspired by the Czech legal regulation ${ }^{2}$. Within the article we will focus on its basic aspects and legal institutes in detail further in the text.

\section{SELECTED SUBSTANTIAL ASPECTS OF CORPORATE CRIMINAL LIABILITY IN THE SLOVAK REPUBLIC}

Act No. 91/2016 Coll. on Corporate Criminal Liability and on Amendments and Supplements to Certain Acts represents a special Act which was incorporated into the basic body of laws regulating substantive and procedural criminal law. In terms of the mutual relationship between this Act and general laws regulating criminal law, i.e. Criminal Code and Act No. 301/2005 Coll. Code of Criminal Procedure as subsequently amended (hereinafter only referred to as "Code of Criminal Procedure"), the ACCL is a lex specialis nature. Under Section 1(2) of ACCL, the application of the Criminal Code and Code of Criminal Procedure is subsidiary whereas this Section reads as follows

"...unless provided by this Act otherwise and unless it is excluded due to the nature of a matter, the Criminal Code shall be applicable to corporate criminal liability and to penalties imposed on a legal

2 Act No. 418/2011 Coll. on Corporate Criminal Liability and on Procedure against Corporations as amended. 
entity and the Code of Criminal Procedure shall be applicable to criminal procedure conducted against a legal entity." General provisions of the Criminal Code and Code of Criminal Procedure which represent lex generalis shall apply only where there is no special regulation on the given matter and, at the same time, unless it is excluded due to the nature of a matter. An example of a situation where the provisions of the Criminal Code shall be applied is e.g. the definition of a criminal offence, which is not set out in the ACCL. On the other hand, the provisions of the Criminal Code regulating the prison sentence are not applicable since their application vis-à-vis a legal entity is excluded primarily due to its nature. The subsidiary application of the provisions contained in the Code of Criminal Procedure shall be used e.g. in bringing charges or filing an indictment. However, the provisions of the Code of Criminal Procedure regulating custody shall not be applied since this legal institute may not be applied vis-à-vis the legal entity.

The subject matter of the ACCL includes both substantive as well as procedural aspects of corporate criminal liability and its scope is defined in Section 1(1) which may be divided into three basic areas:

a) introductory provisions and the basics of corporate criminal liability (subject matter of the Act and its relationship to other laws, applicability of the Act, criminal offences committed by legal entities, corporate criminal liability - based on the attributability model, exclusion of criminal liability of some legal entities, defining a legal entity as an offender, accomplice, abettor, criminal liability of a legal successor to a legal entity, effective regret and expungement of criminal record),

b) criminal sanctions (principles applied in sentencing and individual types of penalties) and

c) criminal procedure conducted against legal entities (relation to the procedure conducted for commission of an administrative delict, territorial jurisdiction, notification about the commencement and termination of the criminal procedure, change, winding-up and termination of a legal entity, restrictive and securing measures, acting on behalf of a legal entity in the criminal procedure, defence counsel, examination, closing arguments, final word and provisions on the execution of certain penalties).

Some authors ${ }^{3}$ criticize the regulation contained in ACCL for lacking the definition of the purpose of the Act. However, the very source for its inspiration, the Czech legal regulation thereof, does not encompass an explicit definition of the purpose of the Act either. We, though, have to agree with the above-mentioned authors stating that the Czech legal regulation does not expressly contain the definition of the purpose of the Act but this may be implied from its Explanatory Memorandum. However, the Explanatory Memorandum to ACCL does not state, why solely the criminal sanctions imposed on individuals are no longer enough. This Explanatory Memorandum, in its General Part, deals especially with international commitments of the Slovak Republic which call on effective sanctioning of legal entities or it deals with various concepts of corporate criminal or administrative liability. This eventually creates an impression that the purpose of ACCL is not the need to hold legal entities criminally liable and sanction them for committing grave criminal activities but rather to keep the international commitments binding on the Slovak Republic.

There is even no definition of a legal entity contained in the provisions of ACCL. Neither the Criminal Code, nor the Code of Criminal Procedure, nor any other criminal regulations actually

3 MENCEROVÁ, I., TOBIÁŠOVÁ, L. Možnosti trestnej zodpovednosti právnických osôb pri eliminovaní ekonomickej kriminality v kontexte naplnenia účelu a funkcií trestného práva. In: Bratislavské právnické fórum 2015 [elektronic source], Bratislava: Comenius University, Faculty of Law, 2015., p. 1276 - 285 [CD-ROM]. 
contain the definition of a legal entity. A part of the professional public ${ }^{4}$ states that the term "legal entity is defined by civil law, commercial law or even administrative law regulations. However, these "non-criminal" regulations do not contain such definition. Pursuant to the provisions of Section 18(2) of Act No. 40/1964 Coll. Civil Code as subsequently amended (hereinafter referred to as the "Civil Code"), the following entities shall be considered as legal entities: associations of individuals or legal entities, purpose-made associations of property, territorial self-governing units or other entities defined as legal entities by an Act. According to the Civil Code, the basic elements of a legal entity are: its name, registered office, the way it was established and the way in which the legal entity acts $^{5}$. These facts can subsequently lead to the determination of the main features of a legal entity, i.e. its organisation, personnel or property base, purpose and own legal personality ${ }^{6}$, but the Civil Code does not provide its very definition. According to Lazar ${ }^{7}$, the Slovak legal regulation of legal entities represents "a compromise between the theory of fiction and theory of reality". Pursuant to the Explanatory Memorandum to ACCL, legal entities represent a legal subject which is different from a natural person and these subjects are created artificially by law which confers on them a capacity to have rights and obligations, to perform legal and unlawful acts and which can be held liable in legal relationships.

\section{CONDITIONS GIVING RISE TO CORPORATE CRIMINAL LIABILITY}

The introduced model of genuine corporate criminal liability in the Slovak Republic may be described in a more simplified way through the obligatory elements of corporate criminal liability. A criminal offence is committed by a legal entity provided that the following conditions are met cumulatively:
a) a criminal offence set out in an exhaustive list of criminal offences
b) was committed by a natural person in a particular relation to a legal entity
c) for its benefit or on its behalf, as part of or through its activities and it
d) was attributed to a legal entity.

\subsection{Criminal offences}

Generally, the basic prerequisite for a criminal liability is the commission of a criminal offence. A criminal offence is defined in Section 8 of the Criminal Code as "any unlawful act that meets the elements set out in this Act, unless this Act provides otherwise." Apart from the definition of a criminal offence itself, the Criminal Code further refers to and describes the obligatory elements of a criminal offence and at the same time it establishes a catalogue of criminal offences for the commission of which a subject shall be held criminally liable. One of the obligatory elements of the criminal offence is a subject which also encompass a criminally liable legal entity in addition to a criminally

4 POLÁK, P., BEZÁK, M. Definícia právnickej osoby, ako jeden z predpokladov jej trestnej zodpovednosti. In: Trestná zodpovednost právnických osôb. Proceedings from an international academic conference held on 12 November 2009, $1^{\text {st }}$ edition. Bratislava: EUROKÓDEX, 2009, p. 141.

5 PATAKYOVÁ, M. et al. Obchodný zákonník. Komentár. Prague: C. H. Beck, 2010, p. 156.

6 LAZAR, J. et al. Občianske právo hmotné, Všeobecná čast'. Bratislava: Iuris Libri, 2014, p. 155.

7 Ibid. p. 155. 
liable natural person. However, a legal entity is held criminally liable only for those criminal offences which are expressly set out in Section 3 of ACCL. The Slovak Republic has fallen within the group of countries which favour the criminal liability of a legal entity for a closed number (numerus clausus) of criminal offences. We believe that the decision made by the legislator to clearly specify the group of criminal offences for the commission of which a legal entity may be held criminally liable was a positive one as far as the foreseeability of law and legal certainty is concerned and it also corresponds to the principle of nullum crimen sine lege certa (no crime without specific law). On the other hand, certain criticism has been made by the professional public ${ }^{8}$, which considers this exhaustive list of criminal offences to be insufficient and not corresponding to the effort to establish an effective tool to combat the corporate criminality. The given closed number (numerus clausus) is a shorter version of a list containing almost 250 criminal offences set out in 12 chapters in the Special Part of the Criminal Code.

The extent of the exhaustive list of criminal offences for the commission of which a legal entity may be held criminally liable was changing during the legislative process and it was narrowed down to the final number (as of 1 July 2016 ACCL has come into effect) of 75 criminal offences stipulated in Section 3 of ACCL from the originally proposed number of 107 criminal offences. The Explanatory Memorandum explains the definition of the catalogue of criminal offences for which legal entities is held criminally liable. Such selection of criminal offences was determined by international commitments of the Slovak Republic arising out of international treaties to which the Slovak Republic is a party and which are binding on it and also by the commitments of the Slovak Republic arising out its membership in the European Union. The Explanatory Memorandum states that individual interests of the Slovak Republic (besides the interests in performing international and EU membership commitments) are represented solely by a narrow group of so-called tax criminal offences, which were added to this exhaustive list due to their nature and experience gained in application practice. Moreover, the Explanatory Memorandum predicts another modification of the catalogue of criminal offences but only with respect to a continuous development of international matters and not as an expression of an interest of the Slovak Republic to combat corporate criminality. As of October 2019, ACCL has been amended three times, with each amendment expanding the range of offenses (35 crimes were added) for which a legal entity can be held criminally liable.

As far as the gravity, forms of causation and types of consequences of criminal offences are concerned, the nature of the catalogue of an exhaustive list of criminal offences is various. This exhaustive list of criminal offences under Section 3 of ACCL for the commission of which a legal entity may be held criminally liable has the following current form:

- illicit manufacturing of narcotics or psychotropic substances, poisons or precursors, their possession and trafficking in them under Sections 172 and 173, spreading drug addiction under Section 174 (Criminal Offences against Life and Limb - Chapter 1 of the Special Part of the Criminal Code);

- human trafficking under Section 179, sexual violence under Section 200, sexual abuse under Sections 201 and 202 (Criminal Offences against Freedom and Human Dignity - Chapter 2 of the Special Part of the Criminal Code);

8 See also: FEDOROVIČOVÁ, I. Zamyslenie sa nad redukciou taxatívneho výpočtu majetkových a hospodárskych trestných činov v návrhu zákona o trestnej zodpovednosti právnických osôb. In: Bratislavské právnické fórum 2015 [electronic source], Bratislava : Comenius University, Faculty of Law, 2015. - p. 1190-1194 [CD-ROM] and PROKEINOVÁ, M. Ekonomická kriminalita ako jeden z dôvodov zavádzania trestnej zodpovednosti právnických osôb. In: Bratislavské právnické fórum 2015 [electronic source], Bratislava : Comenius University, Faculty of Law, 2015. - p. 1309-1315 [CD-ROM]. 
- endangering moral education of youth under Section 211 (Criminal Offences against Family and Youth - Chapter 3 of the Special Part of the Criminal Code);

- embezzlement under Section 213, fraud under Section 221, credit fraud under Section 222, insurance fraud under Section 223, capital fraud under Section 224, subsidy fraud under Section 225, fraudulent bankruptcy under Section 227, induced bankruptcy under Section 228, illegal gambling and wagers under Section 229, illegal lotteries and similar games under Section 229, sharing under Section 231 and 232, money laundering under Section 233 and 234, usury under Section 235, breach of trust by maladministration of estates of another under Section 237, harm done to a creditor under Section 239, preferential treatment of a creditor under Section 240, unauthorised access to computer system under Section 247, unauthorised interference with computer system under Section 247a, unauthorised interference with computer data under Section 247 b, unauthorised interception of computer data under Section $247 \mathrm{c}$, production and possession of an access device, computer system password or similar data under Section 247d (Criminal Offences against Property - Chapter 4 of the Special Part of the Criminal Code);

- unlawful business activity under Section 251, unlawful employment under Section 251a, illegal alcohol, tobacco and tobacco products production under Section 253, breach of regulations governing imports and exports of goods under Section 254, distortion of data in financial and commercial records under Section 259 and 260,damaging the financial interests of the European Union under Sections 261 to 263, insider trading under Section 265, market manipulation under Section 265a, deceitful practices in public procurement and public auction under Section 266 and 267, causing harm to consumers under Section 269, unfair commercial practices against consumers under Section 269a, forgery, fraudulent alteration and illicit manufacturing of money and securities under Section 270 , uttering counterfeit, fraudulently altered and illicitly manufactured money and securities under Section 271, manufacturing and possession of instruments for counterfeiting and forgery under Section 272, tax and insurance evasion under Section 276, payroll tax and insurance evasion under Section 277, tax fraud under Section 277a, failure to pay tax and insurance under Section 278, obstruction of tax administration under Section 278a, breach of regulations governing state technical measures for labelling goods under Section 279, (Economic Criminal Offences - Chapter 5 of the Special Part of the Criminal Code);

- endangering public safety under Sections 284 and 285, illegal arming and arms trafficking under Section 294 and 295, establishing, organising and supporting a criminal group under Section 296, establishing, organising and supporting a terrorist group under Section 297, illicit manufacturing and possession of nuclear materials, radioactive substances, highly hazardous biological agents and toxins under Section 298 and 299, endangering and damaging the environment under Sections 300 and 301, unauthorised handling of waste under Section 302, unauthorised discharge of pollutants under Section 302a, breach of water and air protection regulations under Section 303 and 304, breach of plant and animal species protection regulations under Section 305, breach of tree and shrubbery protection regulations under Section 306 (Criminal Offences against Public Safety and Criminal Offences against the Environment - Chapter 6 of the Special Part of the Criminal Code);

- terror under Sections 313 and 314 (Criminal Offences against the Republic - Chapter 7 of the Special Part of the Criminal Code);

- passive bribery under Sections 328 to 330, active bribery under Sections 332 to 334, trading in influence under Section 336, obstructing the execution of an official decision under Section 348 
and 349, counterfeiting and altering a public Instrument, official seal, official seal-off, official emblem and official mark under Section 352, smuggling of migrants under Section 355 and 356, (Criminal Offences against Public Order - Chapter 8 of the Special Part of the Criminal Code);

- violence against a group of citizens and against an individual under Section 359, serious threats under Section 360, pandering under Section 367, production of child pornography under Section 368, dissemination of child pornography under Section 369, possession of child pornography and participation in child pornographic performance under Section 370, endangering morality under Sections 371 and 372 (Criminal Offences against Other Rights and Freedoms Chapter 9 of the Special Part of the Criminal Code);

- terrorist attack under section 419, some forms of participation in terrorism under section 419b, financing of terrorism under section 419c, traveling for the purpose of terrorism under section $419 \mathrm{~d}$, establishing, supporting and promoting a movement aimed at suppression of fundamental rights and freedoms under Sections 421, sympathizing with a movement aimed at suppression of fundamental rights and freedoms under Sections 421, production of extremist materials under Section 422a, dissemination of extremist materials under Section $422 \mathrm{~b}$, possession of extremist materials under Section 422c, denial or approval of the Holocaust and crimes of political regimes denial and crimes against humanity under Section 422d, defamation of a nation, race or conviction under Section 423, incitement to national, racial or ethnic hatred under Section 424, apartheid and discrimination against a group of persons under Section 424a of the Criminal Code and inhumanity under Section 425 of the Criminal Code (Criminal Offences against Peace, Humanity, Criminal Offences of Terrorism, Extremism and War Criminal Offences - Chapter 12 of the Special Part of the Criminal Code).

\subsection{Natural persons in a particular relation to a legal entity}

Defining the range of natural persons who are in a certain relationship to a legal entity (the criminal offences of which are attributed to a legal entity) only represents a formal condition of a corporate criminal liability defining the essence of unlawful conduct of a legal entity through natural persons ${ }^{9}$. The Explanatory Memorandum emphasizes the fact that the formation and existence of legal entities represents a certain legal construction. Therefore, even the way in which legal entities act shall also be constructed by law since the legal entities are legal subjects who do not have any will and are thus not able to act in accordance with such own will and express it externally. Due to the aforementioned reasons, the law stipulates that the action of a legal entity is represented by those expressions of will which are, on behalf of a legal entity, presented by bodies which the legal entity designates or the representatives of a legal entity who are natural persons. According to the nature of a relationship to a legal entity, natural persons may be divided into two groups: (i) natural persons with a certain type of decision-making or supervisory power; and (ii) natural persons with an "ordinary employees" status.

The first group of natural persons stipulated in the provisions of Section 4(1)(a) to (c) of ACCL includes:

a) statutory body or a member of a statutory body;

b) any person who performs supervisory activities or inspection in the legal entity, or

c) another person who is authorised to represent a legal entity or make decisions on its behalf.

9 ŠÁMAL, P. et al. Trestní odpovědnost právnických osob. Komentář. $1^{\text {st }}$ edition. Prague: C. H. Beck, 2012, p. 173. 
The second group of natural persons is set out in Section 4(2) of ACCL. These natural persons acted as part of authorisations which they were granted by a legal entity. The Bill on CCL in the past contained the definition of this group of people in Section 4(1)(d) stating that they represent any other employee or a person who holds a similar function in performing its work tasks. We believe that such definition could be held and considered as more suitable because we opine that the term "person who acted as part of the authorisation granted to such person by a legal entity" fails to be sufficiently definite and it is currently rather difficult to estimate the extent of the definition of this term in a rather broad range of natural persons who are in a particular relationship to a legal entity.

Naturally, the division of natural persons who are in a particular relationship to a legal entity into two groups is not autotelic. The essence of such division lies in different criteria of possibilities of a legal entity to release itself from criminal liability. Under Section 4(3) of ACCL, a legal entity may be released from criminal liability (by showing that it has a compliance programme in place) ${ }^{10}$ only where criminal offences are attributed to natural persons who are employees or persons stipulated in Section 4(1) of ACCL who do not have any governing or supervisory power.

From the practical viewpoint, the legal entity (most of the times we talk about the business corporation) is most often represented by its statutory body.

In terms of Slovak Republic and the representation of the legal entity, the institute of "procuration" is also used very often by the corporations ${ }^{11}$. By means of a procuration, an entrepreneur entitles the proxy to perform all legal acts involved in operating the enterprise, even though a special power of attorney might otherwise be required to perform such acts. Procuration may only be granted to a natural person. The procuration does not authorise the proxy to alienate real estates or encumber them, unless such authorisation is expressly granted by the procuration.

Apart from procuration, Slovak Commercial Code enables the entrepreneur to establish the branch of an enterprise. Pursuant to section 13/5 of the Commercial Code the head of a branch of an enterprise or the head of a foreign person's enterprise who is entered in the commercial register is entitled to undertake any legal acts relating to such branch or enterprise on the entrepreneur's behalf. In these abovementioned situations, we talk about the natural persons that are enlisted and registered within the respective commercial register. Such registration within the commercial register gives them the authorization to act on behalf of the company.

Private law in Slovakia is not based on the concept of "ultra vires" doctrine. This means that event though the statutory body exceeds the scope of the subject of entrepreneurial activity, entrepreneur shall be bound by the conduct of persons exercising the authority of the statutory body.

Apart from this, the Slovak law enables also other natural persons (mostly employees) to act on behalf of the legal entity without the necessity of the written authorization. The Commercial Code stipulates $^{12}$ that any person entrusted with performance of a certain activity in the operation of an enterprise is entitled to undertake all acts usually involved in the course of such activity. If a person exceeds the powers conferred on him/her under the previous sentence, the legal entity shall only be bound by such conduct if a third party was not aware that such person had exceeded his/her powers and, in the light of all the circumstances of the case, could not have been aware that such person had exceeded his/her powers.

10 For further information see KURILOVSKÁ, L., KORDÍK, M. Intragroup compliance agreement as a tool to manage the risks in the daughter company. In: Enterpreneurship and sustainability issues č. 4 (2018), p. 1008 - 1020.

11

Section 14 of an Act No. 513/1991 Coll. Commercial Code as amended.

12 Section 15 of an Act No. 513/1991 Coll. Commercial Code as amended. 
As we can see from the abovementioned section 15, the Slovak law is very wide when it comes to the possibility of the representation of the legal entity by the persons not being registered in the commercial register, potentially being the employees or other persons empowered to act on behalf of the entrepreneur. The person shall also be empowered to act and perform the activities that are the activities related to the operation of an enterprise. ${ }^{13}$ The Supreme Court of Czech Republic ${ }^{14}$ stipulates that the authorization is not unlimited though, it entails usually involved activities in the course of such activity and such "usualness" shall be determined objectively, irrespectively and independently from its definition in the intragroup documents and regulations.

Furthermore, such rule entailed in the Section 15 of the Commercial Code is strict and the entrepreneur cannot exclude its general applicability. ${ }^{15}$ Slovak Supreme Court stipulated that the internal directives are not eligible to limit the capacity of such empowered persons to act on behalf of the entrepreneur. ${ }^{16}$

Finally, the Slovak Commercial Code goes even beyond the abovementioned and stipulates that the entrepreneur is also bound by the conduct of other persons in the entrepreneur's business premises, provided that a third party involved could not have been aware that the said person was not entitled to conduct him/herself in such a manner. ${ }^{17}$

\subsection{Criminal offence committed by a legal entity for its benefit or on its behalf, as part of or through its activities}

According to the Explanatory Memorandum, another prerequisite giving rise to criminal liability is the existence of a causal link between the interest of a legal entity, acting on its behalf, activities carried on by a legal entity (irrespective of the fact whether it carries on an activity for which it has been granted permission or which is registered in a respective register as its official business activity) or the fact that a legal entity only acts as a tool utilised for committing criminal offences and the unlawful conducted of a natural person who is in a particular relationship to a legal entity. However, the legislator does not further specify the assessment of such criteria and we believe that the assessment of cases of holding a legal entity criminally liable is especially disputable in connection with criminal offences committed in its interest when a criminal offence will be committed by its employee acting primarily in his/her interest. The Czech specialist literature defines these alternatively set out conditions as a corrective which shall prevent a legal entity from being held criminally liable for excesses of natural persons who are in a particular relationship to a legal entity. On the other hand, the definition of given conditions or objective elements is broad enough also in ACCL to enable the sanctioning of a legal entity without a broad interpretation. ${ }^{18}$

13 See the decisions of the Supreme Court of the Czech Republic, case no. 32 Odo 766/2003, 32 Odo 1352/2005, 23 Cdo 3568/2009, 32 Odo 1455/2005 available at www.nsoud.cz.

17 Section 16 of the Slovak Commercial Code.

18 KALVODOVÁ, V.: Vybrané aspekty sankcionování právnických osob. In JELíNEK, J. et al. Trestní odpovědnost právnických osob v České republice: Bilance a perspektivy. $1^{\text {st }}$ edition. Prague : Leges, 2013, p. 231. 


\subsection{Attributability}

Attributability is a basic aspect of one of the ways how corporate criminal liability may be understood. According to Heine's classification, this way of understanding corporate criminal liability means that the liability for criminal offences is attributed to a legal entity. Activities (but not only activities or unlawful activities, but a criminal offence, i.e. all of its obligatory elements, are attributed to a legal entity - authors' note) of a certain group of people who are in a required relationship to a legal entity (master and servant) shall thus be attributed to a legal entity. Such legal provision defeats the argument that a legal entity cannot carry on culpable activities since it does not have its own will. Culpable activities are attributed to a legal entity (among other things) from a natural person who is in a particular relationship to such legal entity (both in case of natural persons having certain decision-making or supervisory powers or in case of "ordinary employees"). ${ }^{19}$ There is no express definition of attributability in ACCL (the Bill on CCL contained such definition in Section 4(2), but such provision was left out at the end of the legislative process). However, the Explanatory Memorandum states that the genuine corporate criminal liability model is based in our legal system on the concept of attributability. Attributability, likewise a natural person, is artificially created by law and represents a primary and essential element of genuine corporate criminal liability in the Slovak Republic. Furthermore, it represents one of the obligatory conditions giving rise to corporate criminal liability.

An important difference between the legal regulation contained in ACCL and the Czech legal regulation lies in an institute contained in Section 4(3) of ACCL which established a corrective element in respect of corporate criminal liability. According to the Explanatory Memorandum, the given subsection regulates a material corrective in respect of holding a legal entity criminally liable for unlawful conduct of a person having an "ordinary employee" status which was caused solely by the fact that a legal entity did not satisfy its statutory obligations in supervising and inspecting its employees.

Such criminal offence will not be attributed to a legal entity if the significance of not complying with these obligations is minor given the business activities carried on by a legal entity, the form of committing the crime, its consequences and circumstances under which it was committed. We believe that such change is very positive and may help legal entities release themselves from criminal liability in cases when a legal entity would be held criminally liable for a criminal offence committed by an employee in a very strict way.

The last circumstance which is not referred to as an individual condition giving rise to corporate criminal liability is the issue of a subject of a criminal offence where such subject is a criminally liable legal entity. As we have already mentioned earlier, ACCL does not contain any definition of a legal entity. However, in its Section 5, ACCL regulates its personal applicability and defines the range of legal entities which are exempted from its applicability (a so-called exemption based on substantial law). The given range of legal entities is completely unpunishable and includes the following: a) the Slovak Republic and its authorities, b) other states and their authorities, c) international organisations established under international public law and their authorities, d) municipali-

19 According to Heine's classification, other ways of understanding corporate criminal liability are: (i) original liability of a legal entity for criminal offences; (ii) liability of a legal entity (taking the form of strict liability or absolute liability) a (iii) mixed models. See: HEINE, G. Unternehmen, Straftrecht und Europäische Entwicklung. Österreichische JuristenZeitung, 2000, No. 23-24, p. 817. 
ties and self-governing regions, e) legal entities which, at the time of commission of the criminal offence, were established by operation of law, $\mathrm{f}$ ) other legal entities in a debt whose financial affairs cannot be settled pursuant to the special law governing bankruptcy proceedings ${ }^{20}$. The Explanatory Memorandum explains this exemption by stating that these subjects directly carry out of perform the duties of the State or state administration or they were established by operation of law. Such group also encompasses foreign states and international organisations which arises out of and corresponds to international commitments of the Slovak Republic.

As for the fact that the ACCL has been effective for more than three years, we also analysed the decisions of the courts adopting the relevant measures against the legal entities and imposing the sanctions against the legal entities. We tried to focus on the concept of attributability that should be entailed within the respective court decisions ${ }^{21}$. However, our research showed that the judges did not expressly stipulate the aspects of attributability of the acts of natural person to the legal entity. In most of the decisions, it was solely mentioned that such person is for instance the statutory body of the company and no other test of attributability was made by the judges. ${ }^{22}$

\section{CONCLUSION - PRACTICAL REFLECTIONS ABOUT POTENTIAL EXCESSES IN THE ENFORCEMENT OF THE CORPORATE CRIMINAL LIABILITY}

Finally, in the last chapter of the article we try to analyse the potential practical situations and pitfalls occurring during the business operation of the company that might result into the criminal responsibility of the company.

First pitfall occurs in the situation when the company is run by two executive directors that are entitled to act on behalf of the company independently. One of the executive directors is the executive director responsible for the tax and financial operations, the other one handles the day-to-day operations of the company. In such set-up the pitfall occurs when the executive director responsible for taxes himself (or by binding instruction given to the employee) orders not to pay the company's due taxes. Such his motivation is enhanced by the fact that he will use such money (that were supposed to be used for tax payment) for his own personal interest and leaves the country to the Caribbean country not cooperating in the process of extradition. ${ }^{23}$

In such situation the executive director committed the crime named as failure to pay tax and insurance under Section 278 of the Criminal Code. However, in such situation the crime is com-

20 The only exception within the meaning of section 5(2) of ACCL are those legal entities in which these subjects hold a share. These legal entities may be held criminally liable for a criminal offence committed. These legal entities represent namely business organisations in which the State or its self-governing units hold a share.

21 For the specifics of application of ultima ratio principle in the courts decisions see HAMRANOVÁ, D.: Aplikácia princípu ultima ratio v rozhodovacej praxi. In: Justičná revue. Roč. 69, č. 6-7 (2017), p. 823 - 832.

22 Decision of the Specialized criminal court in Banská Bystrica, case no. 4 T/28/2018, dated 19. 09. 2018, and the Decision of the Specialized criminal court in Pezinok, case no. 2 T/33/2018, dated 23. 10. 2018, and the Decision of the Supreme court of Slovak Republic, case no. 6Asan/1/2017, dated 21. 02. 2018, and the Decision of the Supreme court of Slovak Republic, case no. 6To/7/2017, dated 30. 01. 2019, and the Decision of the Supreme court of Slovak Republic, case no. $1 \mathrm{TdoV} / 1 / 2017$, dated 29. 05. $2018 \mathrm{~m}$ and the Decision of District Court Žiar nad Hronom, case no. 1 T/44/2019, dated 25. 04. 2019, and the Decision of District Court Trebišov, case no. 7 T/122/2018, dated 30. 11. 2018

23 See STRÉMY, T. Tax crimes committed in the Slovak Republic in context of the European Union. In: Cross Border Colloqium in Bratislava "Criminogenic, Criminal, and Criminalized Movements Across Borders. 
mitted by a natural person in a relation to a legal entity (executive director), and for its benefit or on its behalf, as part of or through its activities and it is attributable to a legal entity. This means that such crime is attributable to the company and that company will be punished for such crime even though it is evident that the company does not profit from such situation and that such situation occurred due to the excesses of the executive director.

Even though there is a stipulation in the Section 4/3 of ACCL that says that the criminal offence will not be attributed to a legal entity if the significance of not complying with the obligations is minor given the business activities carried on by a legal entity, the form of committing the crime, its consequences and circumstances under which it was committed; such "whitewash procedure" is not applicable for the executive directors of the companies. This results into the fact that the company will be punished even though it does not benefit from such committed crime, moreover the company is hurt financially by such crime attributable to the company. ${ }^{24}$

Such situation is seen as rather severe from our opinion.

Another question arises in the situations when the so-called "shadow director" 25 instructs the company to act and perform such activities that result into committing the crime. One the one hand, the law $^{26}$ stipulates that such a person is particularly obliged to act with professional care in accordance with the interests of the company and all shareholders/members thereof and when breaching such obligations, they shall hold the same liability as the statutory body or a member of the statutory body. On the other hand, such stipulation is not applicable for the "shadow directors" in the terms when committing the crime by the company when instructed to do so by the shadow director. If the company does not reveal the identity of the shadow director (for example due to the fact that such shadow director has important contacts in the business sphere) and the criminal authorities do not reveal his impact on the company's acts, then he will not be punished for the crimes that he instructed the company to commit. Only the company will be responsible for such crimes. Moreover, if we imagine that the crime committed by the company (instructed by the shadow director as stipulated hereinabove) causes the bankruptcy of this company and maybe also the bankruptcy of other companies that are the creditors of the company, the shadow director should have been persecuted for the crime of induced bankruptcy that has really bad impact on the economic environment.

\section{Bibliography:}

HAMRANOVÁ, D.: Aplikácia princípu ultima ratio v rozhodovacej praxi Denisa Hamranová. In: Justičná revue. Roč. 69, č. 6 - 7 (2017), p. 823 - 832. ISSN 1335-6461.

HEINE, G. Unternehmen, Straftrecht und Europäische Entwicklung. Österreichische Juristen-Zeitung, 2000, No. 23 24 , p. $871-881$.

FEDOROVIČOVÁ, I. Zamyslenie sa nad redukciou taxatívneho výpočtu majetkových a hospodárskych trestných činov v návrhu zákona o trestnej zodpovednosti právnických osôb. In: Bratislavské právnické fórum 2015 [electronic source], Bratislava: Comenius University, Faculty of Law, 2015. p. 1190 - 1194 [CD-ROM]. ISBN 978-80-7160-411-2.

24 For the specifics of court decisions related to the position of executive directors before insolvency courts and courts, see MIKUŠ, Š., BARTALSKÁ, K. Konatel’ v spleti insolvenčného konania v právnej teórii obchodného práva a aplikačnej praxi konkurzných súdov. In: Policajná teória a prax. 2018.

25 The person who exercises the powers of the statutory body or member of the statutory body in actual fact without having been appointed or designated to perform such function also has the obligations of a mandatary.

26 Section 66/7 of the Commercial Code. 
KALVODOVÁ, V. Vybrané aspekty sankcionování právnických osob. In JELÍNEK, J. et al. Trestní odpovědnost práv nických osob v České republice: Bilance a perspektivy. $1^{\text {st }}$ edition. Prague: Leges, 2013, 392 p. ISBN 978-80-87576-58-8.

LAZAR, J. et al. Občianske právo hmotné, Všeobecná čast'. Bratislava: Iuris Libri, 2014, 1415 p. ISBN 9788089635351.

MENCEROVÁ, I., TOBIÁŠOVÁ, L. Možnosti trestnej zodpovednosti právnických osôb pri eliminovaní ekonomickej kriminality v kontexte naplnenia účelu a funkcií trestného práva. In: Bratislavské právnické fórum 2015 [elektronic source], Bratislava: Comenius University, Faculty of Law, 2015. - p. 1276 - 1285 [CD-ROM]. ISBN 978-80-7160-411-2.

MIKUŠ, Š., BARTALSKÁ, K. Konatel’ v spleti insolvenčného konania v právnej teórii obchodného práva a aplikačnej praxi konkurzných súdov. In: Policajná teória a prax. 2018. ISSN 1335-1370.

PATAKYOVÁ, M. et al. Obchodný zákonník. Komentár. 3. vydanie. Prague: C. H. Beck, 2010, 1199 p. ISBN 9788074003141.

POLÁK, P., BEZÁK, M. Definícia právnickej osoby, ako jeden z predpokladov jej trestnej zodpovednosti. In: Trestná zodpovednost právnických osôb. Proceedings from an international academic conference held on 12 November 2009, $1^{\text {st }}$ edition. Bratislava: EUROKÓDEX, 2009, p. 141.

PROKEINOVÁ, M. Ekonomická kriminalita ako jeden z dôvodov zavádzania trestnej zodpovednosti právnických osôb. In: Bratislavské právnické fórum 2015 [electronic source], Bratislava: Comenius University, Faculty of Law, 2015. p. 1309 - 1315 [CD-ROM]. ISBN 978-80-7160-411-2.

ŠÁMAL, P. et al. Trestní odpovědnost právnických osob. Komentář. $1^{\text {st }}$ edition. Prague: C. H. Beck, 2012, 992 p. ISBN 978-80-7400-592-3.

\section{Contact information:}

JUDr. Jakub Lorko, PhD.

jakub.lorko@flaw.uniba.sk

Comenius University in Bratislava,

Faculty of Law

Šafárikovo nám. 6, P. O. BOX 313

81000

Bratislava

Slovak Republic

JUDr. Matej Smalik, PhD.

matej.smalik@flaw.uniba.sk

Comenius University in Bratislava,

Faculty of Law

Šafárikovo nám. 6, P. O. BOX 313

81000

Bratislava

Slovak Republic 